\title{
REKOMENDASI SEMILOKA NASIONAL KONSERVASI BIODIVERSITAS UNTUK PERLINDUNGAN DAN PENYELAMATAN PLASMA NUTFAH DI PULAU JAWA, SURAKARTA 17-20 JULI 2000
}

Yth.

1. Menteri Kehutanan dan Perkebunan

2. Menteri Negara Lingkungan Hidup

3. Menteri Dalam Negeri

4. Ketua DPR RI

5. Gubernur Propinsi Jawa Tengah

6. Gubernur Propinsi Jawa Timur

7. Ketua DPRD Propinsi Jawa Tengah

8. Ketua DPRD Propinsi Jawa Timur

9. Bupati Kabupaten Karanganyar

10. Bupati Kabupaten Wonogiri

11. Bupati Kabupaten Sragen

12. Bupati Kabupaten Magetan

13. Bupati Kabupaten Ngawi

14. Ketua DPRD Kabupaten Karanganyar

15. Ketua DPRD Kabupaten Wonogiri

16. Ketua DPRD Kabupaten Sragen

17. Ketua DPRD Kabupaten Magetan

18. Ketua DPRD Kabupaten Ngawi

19. Direksi Perum Perhutani

20. Semua pihak terkait.

Assalamu'alaikum Wr. Wb.

Dengan mengucap syukur alhamdulillah, bersama ini kami sampaikan rumusan rekomendasi kegiatan "SEMILOKA NASIONAL KONSERVASI BIODIVERSITAS UNTUK PERLINDUNGAN DAN PenYelamatan Plasma Nutfah di PUlau JAWA", yang diselenggarakan oleh Panitia Konservasi Biodiversitas Flora dan Fauna di Gunung Lawu, Jurusan Biologi FMIPA UNS Surakarta, Kegiatan Seminar dilaksanakan pada tanggal 17-18 Juli 2000, dilanjutkan Lokakarya pada tanggal 19-20 Juli 2000.

Kegiatan ini dilatarbelakangi tingginya tingkat kerusakan alam/habitat di Pulau Jawa, serta belum adanya kawasan konservasi setingkat Taman Nasional di daratan Pulau Jawa bagian tengah, khususnya Propinsi Jawa Tengah, oleh karenanya dirasa perlu adanya upaya untuk turut serta memberikan sumbang saran dalam permasalahan ini, serta mendorong terbentuknya kawasan konservasi di wilayah tersebut, sehingga usaha perlindungan, penyelamatan, penelitian dan pemanfaatkan kekayaan hayati di Jawa dapat dioptimalkan. Adapun garis besar rekomendasi kegiatan tersebut adalah:

Visi:

1. Mempertahankan status Gunung Lawu sebagai sumber air bagi masyarakat di sekitarnya pada khususnya dan di Pulau Jawa pada umumnya. 
2. Melestarikan sumber daya alam hayati dan ekosistem di Gunung Lawu (keanekaragaman hayati) sebagai modal dasar pembangunan yang berkelanjutan.

Misi:

1. Melakukan upaya konservasi sumber daya alam dan lingkungan di Gunung Lawu melalui pendekatan bioprospecting.

2. Mengupayakan perubahan status hutan produksi di sekitar Gunung Lawu menjadi hutan lindung untuk memperluas kawasan konservasi, serta sebagai langkah awal peningkatan status perlindungan kawasan tersebut hingga tingkat taman nasional.

Harapan kami, rekomendasi ini mendapatkan perhatian dan tanggapan sebagaimana mestinya, sehingga upaya pelestarian sumber daya alam dan lingkungan di Gunung Lawu khususnya dan di Pulau Jawa pada umumnya dapat menjadi agenda bersama yang mendesak untuk dikerjakan, mengingat penurunan kualitas lingkungan di Jawa terus berlangsung, sedangkan upaya konservasi memerlukan tindakan yang terus-menerus, bersifat jangka panjang dan lintas sektoral.

Demikian surat pengantar kami, atas perhatian dan kerjasamanya diucapkan terimakasih.

Wassalamu'alaikum Wr. Wb.

Surakarta, 20 Juli 2000

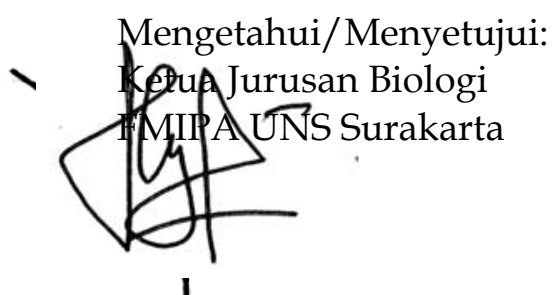

Ketua Panitia/

Koordinator Persidangan,

\section{Drs.'Sunarto, M.S.}

NIP. 131947766
Ahmad Dwi Setyawan, S.Si. NIP. 132162556

Tembusan:

1. Yth. Rektor UNS Surakarta

2. Yth. Dekan FMIPA UNS Surakarta

3. Arsip 


\section{REKOMENDASI SEMILOKA NASIONAL KONSERVASI BIODIVERSITAS UNTUK PERLINDUNGAN DAN PENYELAMATAN PLASMA NUTFAH DI PULAU JAWA, SURAKARTA, 17-20 JULI 2000}

\section{BAB I PENDAHULUAN}

Degradasi sumber daya alam hayati dan ekosistem (keanekaragaman hayati; biodiversitas) di Indonesia - yang merupakan center of megabiodiversity dunia - berlangsung relatif cepat. Hal ini dikarenakan tejadinya perubahan peruntukan, kebakaran hutan, perburuan, pemanenan yang berlebih dan lain-lain. Degradasi yang sama berlangsung jauh lebih cepat di Pulau Jawa, yang merupakan hot spot biodiversitas di Indonesia. Jumlah dan pertambahan penduduk yang tinggi merupakan sebab utama tejadinya kondisi ini. Terlebih krisis ekonomi yang melanda Indonesia sejak akhir tahun 1997, menyebabkan para cukong dan masyarakat di sekitar hutan dan kawasan konservasi tidak lagi terlalu takut untuk melakukan pengambilan secara ilegal hasil hutan di sekitarnya. Oleh karena itu konservasi sumber daya alam hayati di Pulau Jawa merupakan tindakan yang mendesak dilakukan.

Pada saat ini kawasan konservasi di Jawa meliputi: hutan lindung, cagar alam, suaka margasatwa, kebun raya, kebun binatang/taman safari taman hutan raya dan taman nasional. Salah satu kawasan perlindungan in situ yang sangat sesuai dengan UU No. 5 tahun 1990 tentang Konservasi Sumberdaya Alam Hayati dan Ekosistemnya adalah taman nasional mengingat tujuan pendiriannya relatif lengkap mencakup bidang pendidikan, perlindungan, pariwisata, pemberdayaan ekonomi dan lain-lain, serta dalam menepmennya dikenal adanya zonasi.

Hingga saat ini di Jawa, terdapat dua taman nasional laut yaitu TNL Kepulauan Seribu dan TNL Karimunjawa, serta tujuh taman nasional Tiga lokasi di Jawa Barat, yaitu TN Ujung Kulon, TN Gunung Gede Pangrango dan TN Gunung Halimun, serta empat lokasi di Jawa Timur yaitu TN Menr Betiri TN Alas Purwo, TN Baluran dan TN Bromo-Te gerSemeru. Akan tetapi di Jawa Tengah belum terdapat kawasan perlindungan setingkat taman nasional meskipun propinsi ini memiliki sifat ekologi khas, karena merupakan daerah peralihan ekologi Jawa Barat yang cenderung basah dan Jawa Timur yang kering. Sebagai daerah peralihan, Tawa Tengah memiliki mikroklimat khas yang hanya memungkinkan kehidupan spesies tertentu, serta terdapat pula spesies-spesies khas Jawa Timur yang tidak terdapat di Tawa Barat, demikian pula sebaliknya. Oleh karenanya perlu dilakukan upaya mendorong terbentuknya kawasan konservasi setingkat taman nasional di Jawa Tengah.

Kawasan pegunungan dikenal sebagai pusat keanekaragaman hayati di Pulau Jawa, salah satunya Gunung Lawn yang merupakan kawasan ekologi khas Propinsi Jawa Tengah. Gunung ini memitiki luasan yang cukup sehingga memungkinkan kehidupan berbagai jenis makhluk hidup, termasuk adanya ekosistem yang masih alami dan adanya flora-fauna langka/endemik. Di Gunung ini iuga terdapat berbagai bentuk gejala alam, petilasan/ peninggalan purbakala, sumber daya hutan, potensi spiritual dan lain-lain yang memungkinkan dikembangkannya pariwisata. Di samping untuk tujuan pendidikan, penelitian, pemberdayaan ekonomi masyarakat di sekitarnya dan lain-lain. 


\section{BAB II \\ REKOMENDASI \\ KEPADA PEMERINTAH KABUPATEN}

\section{Kabupaten Karanganyar}

Pimpinan Sidang/Kunjungan Lapangan :

Dra. Okid Parama Astirin, M.S.

Jurusan Biologi FMIPA UNS

Peserta

1. Ir. Bambang Supriono

2. Ir. Heru Budiyanto

3. Ev. A. R. V. Haryono, B.Sc. Tourism

4. Sofyan

5. Kades Plumbon

6. Muhammad Da'i, S.Si., Apt.

7. Agus Sutrisno

8. Widya Mudyantini, S.Si.

9. Agus Purwoko

10. Andri Mahyugi G.

Bapedalda Tk. II Karanganyar

Bapedalda Tk. II Karanganyar

Dinas Pariwisata Karanganyar

Asisten Perhutani BKPH Tawangmangu

Kades Plumbon, Tawangmangu

Fakultas Farmasi UMS Surakarta

Bapedalda Tk. II Surakarta

Fakultas Biologi UGM Yogyakarta

Jurusan Biologi FMIPA UNS

Jurusan Biologi FMIPA UNS

Lokasi yang terletak di lereng Gunung Lawu meliputi: Kecamatan Tawangmangu, Ngargoyoso, Jenawi, Jatipuro dan Jumantono.

\section{Lokasi Kunjungan Lapangan:}

1. Desa Plumbon, Kec. Tawangmangu, Kab. Karanganyar

2. Sekipan, Desa Kalisoro, Kec. Tawangmangu, Kab. Karanganyar

3. Candi Sukuh, Kab. Karanganyar

R e k o m e n d a s i

1. Pelibatan masyarakat secara aktif dalam pelestarian kawasan Gunung Lawu dapat dilakukan apabila kesejahteraan ekonomi masyarakat terpenuhi. Salah satu upaya peningkatan pendapatan masyarakat adalah pengembangan budidaya tanaman obat, mengingat kebutuhan pasar dan nilai jual relatif tinggi sedang biaya budidaya rendah, terlebih tanaman ini dapat ditanam pada lahan yang tidak memungkinkan bagi pertumbuhan sayuran, bahkan di sela-sela tanaman kehutanan. Selanjutnya upaya ini perlu ditindaklanjutri dengan peningkatan nilai tambah, melalui produk simplisia, ekstrak sederhana dan pembuatan sediaan sederhana. Pemberdayaan ekonomi melalui usaha peternakan/ penggemukan sapi atau ternak besar tampaknya tidak diperlukan mengingat kebutuhan hijauan yang tinggi dapat merangnsang masyarakat untuk merambah hutan, sedang peternakan hewan kecil seperti kelinci relatif dapat diterima.

2. Konservasi terhadap kerusakan lingkungan akibat penambangan galian $C$, misalnya di Plumbon dapat dilakukan dengan strategi berikut:

a. Penanaman kembali dengan tanaman yang sesuai, antara lain sengon dan jati belanda.

b. Pembuatan zonasi daerah penggalian.

c. Reklamasi bekas galian.

d. Legalisasi dengan pengaturan. 
3. Pemanfaatan nilai ekonomi kawasan di sekitar Gunung Lawu melalui ekowisata tampaknya merupakan tindakan yang paling dapat diterima, untuk itu beberapa hal yang perlu segera dioptimalkan adalah:

a. Pemeliharaan dan peningkatan sarana dan prasarana wisata.

b. Peningkatan promosi dengan pembuatan leaflet dan iklan yang menarik dengan menonjolkan potensi wisata di Karanganyar yang disebarluaskan pada pemberi layanan jasa pariwisata baik domestik maupun asing.

c. Perluasan kawasan wisata Sekipan, hingga mencakup kawasan di sekitarnya yang potensial untuk pariwisata, namun belum dijamah, seperti sendang ayu dan air panas di petak 3. Untuk itu diperlukan peningkatan sarana dan prasarana fisik, serta perbaikan jalan.

4. Adapun demi kelestarian sumber daya alam dan ekosistem di Gunung Lawu perlu dilakukan beberapa tidakan berikut:

a. Penelitian mendalam tentang kehidupan serta keanekaragaman flora dan fauna di Gunung Lawu, termasuk inventarisasi flora dan fauna langka.

b. Penangkaran hewan langka seperti: jalak gading, macan, landak dan lain-lain serta budidaya tanaman langka yang mempunyai nilai ekonomi tinggi terhadap perekonomian rakyat seperti jeruk Tawangmangu.

c. Penentuan kawasan Taman Nasional pada RUTW Kabupaten Karanganyar yang dilengakapi dengan "buffer zone" (daerah penyangga) pada kawasan yang terletak di hutan negara.

\section{Kabupaten Wonogiri}

Pimpinan Sidang/Pendamping Kunjungan Lapangan:

Drs. Wiryanto, M.Si Jurusan Biologi FMIPA UNS Surakarta

\section{Peserta}

1. Bambang Nugroho, B.Sc.

2. Ir. Supatno

3. Lasmo

4. Drs. Hendryk P. Matur

5. Dahsih Ayu Maruti, S.TP

6. Cahyanto Mukti

7. Yuli Irianto

Bagian Lingkungan Hidup Kab. Wonogiri
Bagian Lingkungan Hidup Kab. Wonogiri
Petani Ulat Sutera Wonogiri
Kebun Binatang Surabaya
Bagian Lingkungan Hidup Kab. Cilacap
Jurusan Biologi FMIPA UNS Surakarta
Jurusan Biologi FMIPA UNS Surakarta

Lokasi yang terletak di kompleks Gunung Lawu bagian selatan meliputi tiga kecamatan: Girimarto, Jatipurno dan Bulukerto.

Lokasi Kunjungan

1. Desa Bale Panjang, Kec. Jatipurno, Kab. Wonogiri

2. Desa Bubakan, Kec. Girimarto, Kab. Wonogiri

\section{R e k o m e n d a s i}

1. Perlu dilakukan peningkatan dan pengembangan kawasan konservasi hutan dan lahan.

2. Perlu dilakukan peningkatan dan pengembangan sarana trasportasi antar desa dan antar obyek wisata.

3. Perlu peningkatan pemberdayaan sumberdaya manusia terutama dikawasan sekitar hutan. 
4. Perlu pemanfaatan pulau di tengah waduk Gajah Mungkur dengan pelepasan satwa ke dalamnya disertai penanaman tumbuhan sumber makanannya, sehingga berfungsi konservasi dan meningkatkan daya tarik wisata.

\section{Kabupaten Sragen}

Pimpinan Sidang/Kunjungan Lapangan :

Drs. Marsusi, M.S.

Jurusan Biologi FMIPA UNS Surakarta

Peserta

1. Drs. Sutimbul

BRLKT-Pemda Tk. I Sragen

2. Sugiyono

Camat Sambirejo, Sragen

3. Sandiyo

Kades Bayanan, Sambirejo, Sragen

4. Drs. Soenarto Notosoedarmo, M.Sc.

Fakultas Biologi UKSW Salatiga

5. Ika Puspita Sari, S.Si., M.Si., Apt.

Fakultas Farmasi UGM Yogyakarta

6. Drs. Heri Sulastiono

Bapedalda Tk. II Banyumas

7. Trubus Kurniawan

Universitas Muhammadiyah Surakarta

8. Nurul Aini

9. Herry Djoko P.

Jurusan Biologi FMIPA UNS Surakarta

Jurusan Biologi FMIPA UNS Surakarta

Lokasi yang terletak di lereng Gunung Lawu termasuk dalam Kecamatan Sambirejo.

Lokasi Kunjungan Lapangan:

1. Desa Bayanan, Kec. Sambirejo, Kab. Sragen.

2. Mata air hangat di Desa Jetis, Kec. Sambirejo, Kab. Sragen.

3. Hutan di lereng barat laut Gunung Lawu.

\section{R e k o m e n d a s i}

1. Pengembangan wisata unggulan dapat dilakukan melalui pengembangan empat potensi, yaitu: wanawisata, air hangat, agrowisata dan wisata supranatural.

2. Perlu pengembangan hutan kemasyarakatan, mengingat semakin terbatasnya lahan pertanian masyarakat. Budidaya tanaman under growth pada hutan ini perlu didukung jaringan pemasaran yang kuat, sehingga panenan tetap bernilai jual tinggi.

\section{$\underline{\text { 4. Kabupaten Magetan }}$}

Pimpinan Sidang/Kunjungan Lapangan :

Drs. Sutarno, M.Sc., Ph.D.

Peserta

1. Ir. Darnadi

2. Drs. Sugiyarto, M.Si.

3. Dr. Endang Arisoesilaningsih

4. Drh. Rahmat Suharta

5. Bandung Sahari, S.P.

6. Supriyanto, B.A.

7. Munadianto

8. Anton Wibowo

9. Dyah Amalia Fitri
Jurusan Biologi FMIPA UNS

Kabag. Perekonomian Magetan

Jurusan Biologi FMIPA UNS Surakarta

Jurusan Biologi FMIPA UNIBRAW Malang

Kebun Binatang Surabaya

Wildlife PTIIP Bogor

Bapedalda Tk. II Jepara

Universitas Mulawarman Samarinda

Jurusan Biologi FMIPA UNS Surakarta

Jurusan Biologi FMIPA UNS Surakarta 
Lokasi yang terletak di lereng Gunung Lawu meliputi kecamatan: Plaosan.

Lokasi Kunjungan Lapangan:

1. Jalur pendakian menuju puncak melalui Dusun Cemoro Sewu, Desa Ngancar, Kec. Plaosan, Kab. Magetan.

2. Telaga Sarangan, Kec. Plaosan, Kab. Magetan.

\section{R e k o m e n d a s i}

1. Keunggulan:

a. Merupakan daerah penyangga air (mempunyai fungsi hidrologis), yang vital untuk daerah sekitarnya.Ada spesies spesifik seperti burung jalak Lawu.

b. Kekayaan biodiversitasnya dapat sebagai bahan obat dan sebagainya.

c. Dukungan masyarakat terhadap konservasi cukup tinggi.

2. Keterbatasan:

a. Tanah vulkanik, solum tanah rendah, topografi berbukit-bergunung dengan lereng curam sangat rentan terhadap erosi dan tanah longsor.

b. Ketersediaan air pada musim kemarau untuk pertanian sangat terbatas.

c. Sumber air satu-satunya penduduk adalah mata air.

d. Masih terjadi perusakan ekosistem (limbah, bahaya api dan lain-lain).

3. Mengingat keunggulan dan keterbatasan di atas, maka kelestarian Gunung Lawu akan dapat diupayakan melalui perubahan status kawasan menjadi Taman Nasional dengan demikian:

a. Fungsi hidrologi dapat dijamin melalui perlindungan/konservasi ekosisten Gunung Lawu.

b. Kelestarian fauna endemik dapat diupayakan.

c. Kesejahteraan masyarakat dapat ditingkatkan melalui pengembangan potensi, antara lain: wanawisata, agrowisata, agroindustri dan sebagainya.

d. Perlu dilakukan zonasi pada areal hutan dan kawasan budidaya di sekitarnya.

\section{$\underline{\text { 5. Kabupaten Ngawi }}$}

Pimpinan Sidang/Kunjungan Lapangan :

Drs. Edwi Mahajoeno, M.Si.

Jurusan Biologi FMIPA UNS

Peserta

1. Ir. Ngadino

Dinas PKT Kab. Ngawi

2. Widodo

3. Daryoko

4. Dra. Ari Wardiyanti

5. Dra. Parmiatun

6. Haris Wahyudi

7. Djoko Santoso, S.Si.

8. Agus Suhartono

9. Dwi Priyanto

Bagian Perekonomian Kab. Ngawi

Asisten Perhutani BKPH Jogorogo

Bapedalda Tk. I Jawa Timur

Bapedalda Tk. I Jawa Timur

Bapedalda Tk. I Jawa Timur

Fakultas Farmasi UGM Yogyakarta

Jurusan Biologi FMIPA UNS

Jurusan Biologi FMIPA UNS

Lokasi yang terletak di lereng Gunung Lawu meliputi empat kecamatan, yaitu: Jogorogo, Kendal, Ngrambe dan Sine.

Lokasi Kunjungan Lapangan:

Hutan di Kec. Jogorogo, Kab. Ngawi. 


\section{R e k o m e n d a s i}

1. Ketersediaan air merupakan kebutuhan mendesak bagi masyarakat di sekitar Gunung Lawu. Oleh karena batas air tanah cukup dalam maka kebutuhan air banyak dicukupi dari mata air. Untuk itu luasan hutan lindung dengan ekosistem alami perlu ditingkatkan.

2. Perlu adanya koordinasi antara Perum Perhutani dengan Pemerintah Daerah, sehingga memperlancar upaya konservasi sumber daya alam dan lingkungan di lereng utara Gunung Lawu.

\section{BAB III \\ REKOMENDASI \\ KEPADA PEMERINTAH DAERAH PROPINSI}

\section{Propinsi Jawa Tengah}

Pimpinan Sidang

Drs. Wiryanto, M.Si

Jurusan Biologi FMIPA UNS Surakarta

\section{Peserta}

1. Dra. Okid Parama Astirin, M.S.

Jurusan Biologi FMIPA UNS

2. Ir. Bambang Supriono

3. Ir. Heru Budiyanto

4. Ev. A. R. V. Haryono, B.Sc. Tourism

Bapedalda Tk. II Karanganyar

Bapedalda Tk. II Karanganyar

5. Sofyan

6. Kades Plumbon

7. Muhammad Da'i, S.Si., Apt.

8. Agus Sutrisno

9. Widya Mudyantini, S.Si.

10. Agus Purwoko

11. Andri Mahyugi G.

12. Bambang Nugroho, B.Sc.

13. Ir. Supatno

14. Lasmo

15. Drs. Hendryk P. Matur

16. Dahsih Ayu Maruti, S.TP

Dinas Pariwisata Karanganyar

Asisten Perhutani BKPH Tawangmangu

Kades Plumbon, Tawangmangu

Fakultas Farmasi UMS Surakarta

Bapedalda Tk. II Surakarta

Fakultas Biologi UGM Yogyakarta

Jurusan Biologi FMIPA UNS

Jurusan Biologi FMIPA UNS

Bagian LH Kab. Wonogiri

Bagian LH Kab. Wonogiri

Petani Ulat Sutera Wonogiri

Kebun Binatang Surabaya

Bagian LH Kab. Cilacap

17. Cahyanto Mukti

18. Yuli Irianto

19. Drs. Marsusi, M.S.

20. Drs. Sutimbul

21. Sugiyono

22. Sandiyo

Jurusan Biologi FMIPA UNS Surakarta

Jurusan Biologi FMIPA UNS Surakarta

Jurusan Biologi FMIPA UNS Surakarta

BRLKT-Pemda Tk. I Sragen

Camat Sambirejo, Sragen

Kades Bayanan, Sambirejo, Sragen

23. Drs. Soenarto Notosoedarmo, M.Sc.

Fakultas Biologi UKSW Salatiga

24. Ika Puspita Sari, S.Si., M.Si., Apt.

Fakultas Farmasi UGM Yogyakarta

25. Drs. Heri Sulastiono

26. Trubus Kurniawan

27. Nurul Aini

28. Herry Djoko P.

Bapedalda Tk. II Banyumas

Universitas Muhammadiyah Surakarta Jurusan Biologi FMIPA UNS Surakarta Jurusan Biologi FMIPA UNS Surakarta 


\section{R e k o m e n d a s i}

1. Perlu upaya pemberdayaan ekonomi masyarakat di sekitar Gunung Lawu dengan memperhatikan kelestarian sumber daya alam dan ekosistem di kawasan tersebut.

2. Perlu adanya penggalakan ekowisata dengan dilandasi pengetahuan yang benar tentang konservasi. Untuk itu perlu didukung dengan peningkatan dan pengembangan sarana trasportasi antar desa dan antar obyek wisata.

3. Perlu adanya pengawasan dan pengaturan yang serius terhadap usaha pertambangan galian $\mathrm{C}$, agar tidak merusak kondisi lingkungan di sekitarnya.

4. Perlu adanya penelitian mendalam tentang kehidupan serta keanekaragaman flora dan fauna di Gunung Lawu, termasuk inventarisasi flora dan fauna langka. Diikuti dengan upaya penangkaran hewan langka dan budidaya tanaman langka, termasuk yang mempunyai nilai ekonomi tinggi.

5. Perlu adanya upaya peningkatan kualitas sumberdaya manusia, terutama di kawasan sekitar hutan.

6. Perlu pengembangan hutan kemasyarakatan, mengingat semakin terbatasnya lahan pertanian. Budidaya tanaman under growth pada hutan ini perlu didukung jaringan pemasaran yang kuat, sehingga panenan tetap bernilai jual tinggi.

7. Perlu adanya upaya perluasan kawasan hutan lindung, sehingga memberi ruang hidup yang cukup bagi ekosistem alami Gunung Lawu.

\section{Propinsi Jawa Timur}

\section{Pimpinan Sidang}

Drs. Sutarno, M.Sc., Ph.D.

\section{Peserta}

1. Ir. Darnaedi

2. Drs. Sugiyarto, M.Si.

3. Dr. Endang Arisoesilaningsih

4. Drh. Rahmat Suharta

5. Bandung Sahari, S.P.

6. Supriyanto, B.A.

7. Munadianto

8. Anton Wibowo

9. Diyah Amalia

10. Drs. Edwi Mahajoeno, M.Si.

11. Ir. Ngadino

12. Widodo

13. Daryoko

14. Dra. Ari Wardiyanti

15. Dra. Parmiatun

16. Haris Wahyudi

17. Djoko Santoso, S.Si.

18. Agus Suhartono

19. Dwi Priyanto
Jurusan Biologi FMIPA UNS

Kabag. Perekonomian Magetan Jurusan Biologi FMIPA UNS Surakarta Jurusan Biologi FMIPA UNIBRAW Malang

Kebun Binatang Surabaya

Wildlife PTIIP Bogor

Bapedalda Tk. II Jepara

Universitas Mulawarman Samarinda

Jurusan Biologi FMIPA UNS

Jurusan Biologi FMIPA UNS

Jurusan Biologi FMIPA UNS

Dinas PKT Kab. Ngawi

Bagian Perekonomian Kab. Ngawi

Asisten Perhutani BKPH Jogorogo

Bapedalda Tk. I Jawa Timur

Bapedalda Tk. I Jawa Timur

Bapedalda Tk. I Jawa Timur

Fakultas Farmasi UGM Yogyakarta

Jurusan Biologi FMIPA UNS

Jurusan Biologi FMIPA UNS 
R e k o m e n d a s i

1. Perluasan kawasan hutan lindung perlu dilakukan, khususnya untuk menjaga ketersediaan air di sekitarnya. Tindakan ini merupakan langkah awal yang dapat memandu ke arah pembentukan taman nasional yang diharapkan dapat menjaga:

a. Fungsi hidrologi.

b. Kelestarian flora dan fauna liar ataupun endemik.

c. Kesejahteraan masyarakat melalui pengembangan berbagai potensi, antara lain: wanawisata, agrowisata, agroindustri dan sebagainya.

d. Menjadi sarana penelitian dan pendidikan

2. Perlu adanya koordinasi antara Perum Perhutani dengan Pemerintah Daerah, sehingga memperlancar upaya konservasi sumber daya alam dan lingkungan di lereng utara dan timur Gunung Lawu.

\section{BAB IV}

\section{REKOMENDASI KEPADA PEMERINTAH PUSAT}

Pimpinan Sidang

Drs. Wiryanto, M.Si

Peserta

1. Dra. Okid Parama Astirin, M.S.

2. Ir. Bambang Supriono

3. Ir. Heru Budiyanto

4. Ev. A. R. V. Haryono, B.Sc. Tourism

5. Sofyan

6. Kades Plumbon

7. Muhammad Da'i, S.Si., Apt.

8. Agus Sutrisno

9. Widya Mudyantini, S.Si.

10. Agus Purwoko

11. Andri Mahyugi G.

12. Bambang Nugroho, B.Sc.

13. Ir. Supatno

14. Lasmo

15. Drs. Hendryk P. Matur

16. Dahsih Ayu Maruti, S.TP

17. Cahyanto Mukti

18. Yuli Irianto

19. Drs. Marsusi, M.S.

20. Drs. Sutimbul

21. Sugiyono

22. Sandiyo

23. Drs. Soenarto Notosoedarmo, M.Sc.

24. Ika Puspita Sari, S.Si., M.Si., Apt.

25. Drs. Heri Sulastiono

26. Trubus Kurniawan

27. Nurul Aini
Jurusan Biologi FMIPA UNS Surakarta

Jurusan Biologi FMIPA UNS

Bapedalda Tk. II Karanganyar

Bapedalda Tk. II Karanganyar

Dinas Pariwisata Karanganyar

Asisten Perhutani BKPH Tawangmangu

Kades Plumbon, Tawangmangu

Fakultas Farmasi UMS Surakarta

Bapedalda Tk. II Surakarta

Fakultas Biologi UGM Yogyakarta

Jurusan Biologi FMIPA UNS

Jurusan Biologi FMIPA UNS

Bagian LH Kab. Wonogiri

Bagian LH Kab. Wonogiri

Petani Ulat Sutera Wonogiri

Kebun Binatang Surabaya

Bagian LH Kab. Cilacap

Jurusan Biologi FMIPA UNS Surakarta

Jurusan Biologi FMIPA UNS Surakarta

Jurusan Biologi FMIPA UNS Surakarta

BRLKT-Pemda Tk. I Sragen

Camat Sambirejo, Sragen

Kades Bayanan, Sambirejo, Sragen

Fakultas Biologi UKSW Salatiga

Fakultas Farmasi UGM Yogyakarta

Bapedalda Tk. II Banyumas

Universitas Muhammadiyah Surakarta

Jurusan Biologi FMIPA UNS Surakarta 
28. Herry Djoko P.

29. Drs. Sutarno, M.Sc., Ph.D.

30. Ir. Darnadi

31. Drs. Sugiyarto, M.Si.

32. Dr. Endang Arisoesilaningsih

33. Drh. Rahmat Suharta

34. Bandung Sahari, S.P.

35. Supriyanto, B.A.

36. Munadianto

37. Anton Wibowo

38. Diyah Amalia

39. Drs. Edwi Mahajoeno, M.Si.

40. Ir. Ngadino

41. Widodo

42. Daryoko

43. Dra. Ari Wardiyanti

44. Dra. Parmiatun

45. Haris Wahyudi

46. Djoko Santoso, S.Si.

47. Agus Suhartono

48. Dwi Priyanto
Jurusan Biologi FMIPA UNS Surakarta Jurusan Biologi FMIPA UNS Surakarta Kabag. Perekonomian Magetan Jurusan Biologi FMIPA UNS Surakarta Jurusan Biologi FMIPA UNIBRAW Malang Kebun Binatang Surabaya

Wildlife PTIIP Bogor

Bapedalda Tk. II Jepara

Universitas Mulawarman Samarinda Jurusan Biologi FMIPA UNS Jurusan Biologi FMIPA UNS Jurusan Biologi FMIPA UNS Dinas PKT Kab. Ngawi Bagian Perekonomian Kab. Ngawi Asisten Perhutani BKPH Jogorogo Bapedalda Tk. I Jawa Timur Bapedalda Tk. I Jawa Timur Bapedalda Tk. I Jawa Timur Fakultas Farmasi UGM Yogyakarta Jurusan Biologi FMIPA UNS Jurusan Biologi FMIPA UNS

\section{R e k o m e n d a s i}

Visi:

1. Mempertahankan status Gunung Lawu sebagai sumber air bagi masyarakat di sekitarnya pada khususnya dan di Pulau Jawa pada umumnya.

2. Melestarikan sumber daya alam hayati dan ekosistem di Gunung Lawu (keanekaragaman hayati) sebagai modal dasar pembangunan yang berkelanjutan.

Misi:

1. Melakukan upaya konservasi sumber daya alam dan lingkungan di Gunung Lawu melalui pendekatan bioprospecting.

2. Mengupayakan perubahan status hutan produksi di sekitar Gunung Lawu menjadi hutan lindung untuk memperluas kawasan konservasi, serta sebagai langkah awal peningkatan status perlindungan kawasan tersebut hingga tingkat taman nasional.

\section{BAB V PENUTUP}

Perlindungan sumber daya alam dan lingkungan, termasuk konservasi sumberdaya alam hayati dan ekosistemnya (keanekaragaman hayati; biodiversitas) merupakan upaya jangka panjang dan memerlukan merhatian serius secara terus menerus. Upaya ini bersinggungan dengan kepentingan berbagai pihak serta memerlukan biaya yang tidak sedikit, oleh karenanya perlu tindakan bersama antara pemerintah, universitas, lembaga penelitian, BUMN/pengusaha, lembaga donor/LSM dan masyarakat setempat. Gunung Lawu merupakan salah satu ekosistem Pulau Jawa yang eksotis dan menjadi sumber air/penghidupan banyak pihak, oleh karenanya memerlukan perhatian bersama. 
Surakarta, 20 Juli 2000

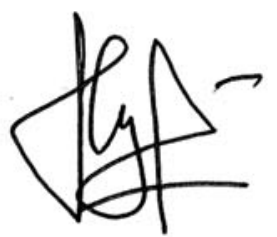

Koordinator Persidangan,

Ahmad Dwi Setyawan, S.Si. NIP. 132162556 